\title{
PENGARUH TASK-TECHNOLOGY FIT DAN UTILIZATION SIAKAD DAN UB-FEEDER TERHADAP DAMPAK KINERJA INDIVIDU DI UNIVERSITAS BRAWIJAYA
}

\author{
Dwi Wahyuningsih ${ }^{1}$, Irwan Noor ${ }^{2}$, M.R. Khairul Muluk ${ }^{3}$ \\ Fakultas Ilmu Administrasi, Universitas Brawijaya \\ Email: $\underline{\text { dwiwahyuningsih77@gmail.com }}{ }^{1}$, irwannoor@yahoo.com² ${ }^{2}$ mr.khairulmuluk@yahoo.com ${ }^{3}$
}

\begin{abstract}
This paper examines the effect of the task-technology fit and Utilization on Siakad and UB-Feeder to the individual performance impact in UB. The research sample is academic staff who use Siakad as well as UB Feeder in Universitas Brawijaya with 99 respondents using the stratified random sampling method. Data was collected using a questionnaire that had been tested for reliability and validity, a measuring instrument with a 5-point Likert scale. The research model uses Technology Performance Chain (TPC) with constructs: Task Characteristic, Technology Characteristics, Task- Technology Fit, Utilization and Performance Impact. Analysis using descriptive statistical analysis (SPSS) and inferential statistical analysis (SEM-PLS). The results of the hypothesis in this study are 1) Task Characteristics have a positive and significant effect on Task-Technology Fit; 2) Technology Characteristics have a positive and significant effect on Task-Technology Fit; 3) Task-Technology Fit has a positive and significant effect on Utilization; 4) Task-Technology Fit has a positive and significant effect on Performance Impact; and 5) Utilization has a positive and significant effect on Performance Impact.
\end{abstract}

Keywords: academic information system, task characteristic, technology characteristic, tasktechnology fit, utilization, performance impact, technology performance chain

\begin{abstract}
ABSTRAK
Tesis ini bertujuan untuk meneliti pengaruh kesesuaian tugas-teknologi Siakad dan UB Feeder terhadap dampak kinerja individu di UB serta pengaruh pemanfaatan Siakad dan UB Feeder terhadap dampak kinerja individu di UB. Sampel penelitian adalah tenaga kependidikan bidang akademik yang menggunakan Siakad sekaligus UB Feeder di Universitas Brawijaya sejumlah 99 responden dengan memakai metode pengambilan sampel stratified random sampling. Data dikumpulkan dengan menggunakan kuesioner yang telah diuji reliabilitas dan validitasnya, alat ukur dengan skala Likert 5 point. Penelitian ini menggunakan model rantai Technology Performance Chain (TPC) dengan konstruk Task Characteristic, Technology Characteristic, Task-Technology Fit, Utilization dan Performance Impact. Analisis menggunakan statistik deskriptif yaitu software SPSS dan Analisis Statistik Inferensial/SEM dengan menggunakan software SmartPLS. Hasil hipotesis dalam penelitian ini adalah 1) Task Characteristik berpengaruh posifif dan signifikan terhadap Task-Technology Fit; 2) Techology Characteristic berpengaruh posifif dan signikan terhadap Task-Technology Fit; 3) Task-Technology Fit berpengaruh posifif dan signifikan terhadap Utilization; 4) Task-Technology Fit berpengaruh posifif dan signifikan terhadap Performance Impact; dan 5) Utilization berpengaruh posifif dan signifikan terhadap Performance Impact.
\end{abstract}

Kata Kunci : sistem informasi akademik, karakteristik tugas, karakteristik teknologi, kesesuaian tugas-teknoogi, pemanfaatan, dampak kinerja, rantai kinerja-teknologi 


\section{PENDAHULUAN}

Perkembangan teknologi informasi (TI) berkembang makin pesat, dan mempunyai peranan penting di sebuah organisasi. Pemanfaatan TI ada di organisasi sektor bisnis dan sektor publik, salah satunya adalah lembaga perguruan tinggi. Keberhasilan sebuah organsasi dalam mencapai tujuannya tergantung pada sumberdaya yang dimilikinya, yaitu man (human), money, material, machine, method, market, minute (waktu) dan informatioan (7M+1). (Amin, 2017)

Dalam Indrayani (2013:629), Hanna, (2003) bahwa pemanfaatan TI dan komunikasi (TIK) dalam pendidikan merupakan kebutuhan mutlak yang harus dioperasikan dan dimanfaatkan oleh perguruan tinggi jika ingin meningkatkan kualitas pendidikan. Untuk pendidikan tinggi, serta kelembagaan modern lainnya, pemanfaatan teknologi informasi tidak hanya berfungsi untuk membantu manajemen (pendukung), namun juga berfungsi untuk memperbaiki (lebih memungkinkan) dalam proses pengambilan keputusan di berbagai tingkat manajemen perguruan tinggi (Indrajit dan Djokopranoto, 20010. Alkawaldeh (2010:1) melakukan penelitian yang bertujuan untuk mengeksplorasi hambatan dalam memanfaatkan TIK dalam proses belajar mengajar di Yordania di lingkup siswa, guru, dan staf administrasi menggunakan model TPC dan ditemukan sejumlah hambatan yang mana sebagian besar diidentifikasikan masuk dalam indikator facilitating conditions. Hambatan ini mayoritas memerlukan peranan dari kementerian pendidikan Yordania agar dapat menyediakan lebih banyak sumber daya dan peluang yang dapat menunjang proses integrsi teknologi ke dalam pendidikan di Yordania.

Penelitian tersebut dibangun di atas karya Goodhue dan ditambahkan ke dalamnya dengan menyelidiki tautan tambahan dalam rantai teknologi-ke-kinerja yang sebelumnya belum diteliti. Mengacu pada hubungan antara evaluasi pengguna tentang kecocokan teknologi tugas dan kinerja, Goodhue (1998) mengemukakan: Penelitian konseptual dan empiris sangat dibutuhkan untuk mengatasi masalah apakah ada hubungan, dan jika demikian, seperti apa, kuat atau lemah.

Penelitian ini dilakukan dilatar belakangi:

1. TI telah dimanfaatkan secara luas di sektor publik khususnya di UB;

2. Adanya pengembangan sistem informasi terutama dibidang akademik sehingga perlu diketahui pengaruhnya terhadap dampak kinerja;

3. Penelitian tentang pegaruh kesesuaian tugasteknlogi dan pemanfaatan Siakad dan UB Feeder terhadap dampak kinerja belum banyak dilakukan di UB;

4. Peneliti ingin membuktikan bahwa pemanfaatan teknologi dapat meningkatkan dampak kinerja.

\section{KAJIAN PUSTAKA}

Menurut Jogianto (2005 dikutip dalam Rizal, 2013:11) kumpuIan elemen yang berinteraksi untuk mencapai sasaran tertentu adalah arti sistem. Sistem ini memberi gambaran mengenai kejadian dan kesatuan nyata misal tempat, barang dan orang yang memang ada dan terjadi. Dengan banyak pendapat tentang sistem dapat dikatakan bahwa sistem adalah kelompok jaringan yang berup unsur dan prosedur sistem bersangkutan yang tak terpisahkan untuk mencapai tujuan yang telah ditentukan. Mc Leod (1995) yang dikutip oleh Al Fatta (2007:9) informasi yaitu data yang telah diproses/data yang punya arti. Jadi disimpulkan bahwa informasi merupakan hasil pengolahan data yang memiliki arti dan bisa dipakai dalam proses pengambilan keputusan dan dapat dipergunakan bagi penerimanya.

Menurut Hutahaean (2014:8) informasi adalah data yang diolah menjadi bentuk yang lebih berguna dan lebih berarti untuk penerimanya. Informasi adalah data yang telah diolah menjadi suatu bentuk yang penting bagi si penerima dan memiliki nilai yang secara nyata dapat dirasakan dalam kepuutsan saat ini atau di masa yang akan datang, ini pendapat Davis yang dikutip oleh Hutahaean (2014:8). Mc Leod (1995) yang dikutip oleh Al Fatta (2007:9) menyatakan informasi merupakan data yang telah diproses/data yang punya arti. Dari banyak pendapat diatas kesimpulannya informasi adalah hasil olah data yang punya arti dan bisa dipakai dalam proses pengambilan keputusan serta bisa dipergunakan bagi penerimanya.

Menurut al Fatta (2007:9) SIM diartikan sebagai suatu alat untuk menyajikan Informasi hingga bermanfaat bagi penerimanya (Kertahadi, 1995) yang bertujuan untuk menyajikan informasi guna pengambilan keputusan di proses perencanaan, pemrakarsaan, pengorganisasian, pengendalian kegiatan operasi subsistem perusahaan dan menyajikan proses sinergi organisasi (Murdick dan Ross, 
1993). Dalam Davis (1995) sistem informasi manajemen terdiri dari elemen perangkat keras komputer (hardware), perangkat lunak (software), database, prosedur dan petugas operasional.

Akademik adalah pendidikan atau proses belajar mengajar. Akademik jika dilihat dari Iatarbelakang terminoIogis iaIah situasi dimana orang bisa menyampaikan dan menerima gagasan, pemikiran atau iImu pengetahuan sekaligus meIakukan pengujian terhadapnya secara jujur, terbuka dan IeIuasa (Munandar, 2008:30 dikutip oleh Rizal 2013:16). SlAKAD merupakan sistem lnformasi bidang akademik yang dibangun untuk memberikan kemudahan pada pengguna dalam aktifitas administrasi akademik kampus secara online, seperti proses penerimaan mahasiswa baru, pembuatan kurikulum, pembuatan jadwal kuliah, pengisian kartu rencana studi, pengisian nilai, pengelolaan data dosen dan mahasiswa, selain itu sistem ini berfungsi sebagai pendukung untuk analisis data dalam menentukan keputusan kampus.

Untuk pelaporan kepada DIKTI, menu pelaporan pada SIAKAD dapat digunakan untuk pelaporan EPSBED kepada DIKTI yang sesuai dengan standart nasional, sehingga mudah dalam pembuatan laporan. Saat ini pelaporan tidak lagi menggunakan fitur EPSBED namun menggunakan UB Feeder, sebuah aplikasi yang dikembangkan oleh TIK UB yang berfungsi untuk menjembatani pelaporan ke sistem forlap DIKTI. Sistem Informasi Akademik yang baik adalah sistem yang dapat mencapai kepuasan dari pengguna, dalam hal ini adalah operator/ pengguna SIAKAD.

Aplikasi Feeder merupakan aplikasi yang dipakai untuk mengelola data mahasiswa dan data perkuliahan masing-masing perguruan tinggi dimana aplikasi ini dikelola sendiri oleh masing-masing perguruan tinggi yang kemudian ditampilkan pada forlap dikti. UB memiliki sistem aplikasi yang digunakan untuk mengelola data mahasiswa dan perkuliahan yang terintegrasi dengan forlap DIKTI yang kami sebut sebagai UB Feeder. Data mahasiswa ini diambil dari aplikasi SIAKAD UB.

Setiap program studi di UB memiliki operator yang bertugas mengolah data tersebut dan menginputkannya pada aplikasi. Data setelah diolah ditampung di web service UB termasuk menampung data yang sudah dilakukan pengolahan oleh berbagai fakultas di UB. Kemudian dilakukan proses sinkronisasi data ke sistem Forlap DIKTI oleh operator induk di akademik UB sehingga data tersebut dapat ditampilkan di web Forlap DIKTI.

Technology to Performance Chain (TPC) merupakan mode1 yang berperan penting di pemanfaatan teknologi yang berpengaruh terhadap dampak kinerja pada tingkat individu. Inti mode1 adalah tentang kesesuaian tugasteknologi yang dihubungkan dengan dampak kinerjanya. TPC merupakan model yang dibangun dari dua aliran penelitian yaitu sikap pemakain (user attitude) sebagai prediktor dari pemanfaatan (utilization) dan kesesuaian tugasteknologi (task-technology fIt) sebagai prediktor dari dampak kinerja.

Gambar dibawah menunjukkan model TPC yang disederhanakan dengan menghilangkan konstruk kepercayaan, dimana model ini telah diuji oleh Goodhue \& Thompson (1995) dan oleh Saepulloh (2018):

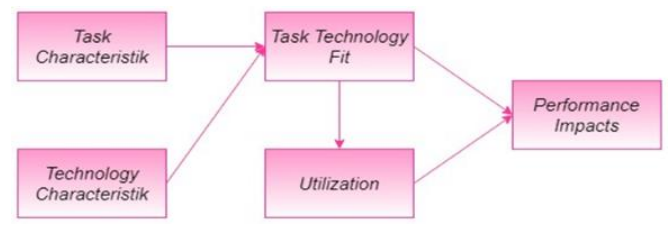

Gambar 1. TPC yang disederhanakan

(Jogiyanto, 2008:531; Saepuloh, 2018:9)

Berdasarkan Goodhue (1993), Perrow (1967) dan Thompson (1967) yang dikutip oleh Jogiyanto (2008:533) mereka membuat konstruk untuk mengukur karakteristik tugas (task characteristic) yaitu:

a. Ketidak-kerutinan (non-routineness), untuk mengklasifikasikan rutin atau tidaknya suatu pekerjaan dengan menggunakan sistem yang ada;

b. Interdependen (interdependence) dengan unit-unit organisasi lainnya, untuk mengklasifikasikan ada atau tidaknya hubungan dengan unit lain yang juga menggunakan sistem yang sama;

c. Titel tugas (job title), untuk mengklasifikasikan pemakai sistem mulai manajemen level rendah sampai level atas.

Karakteristik teknologi menurut jogiyanto (2008:537) diukur dengan:

a. Sistem informasi tertentu yang dipergunakan (particult systems used), diasumsikan bahwa sistem yang dipergunakan dianggap sama;

b. Departemen (Department). Departemen dalam sistem informasi dapat dibedakan dengan departemen pemakai dalam bentuk perhatian, tekanan, prioritas dan hubungan 
manajemennya. Perbedaan ini menimbulkan perbedaan jasa yang diberikan kepada departemen pemakai dari departemen sistem informasi.

Dikutip oleh Agustiarni (2010) TTF merupakan sebuah level dimana teknologi membantu individu daIam pelaksanaan tugasnya. Jadi secara spesifik TTF merupakan penyesuaian antarakebutuhan penyelesaian tugas, kemampuan individu dan fungsi teknologi. Pengaruh TTF terhadap pemanfaatan nampak pada hubungan TTF dan kepercayaan tentang dampak penggunaan sistem, sebab TTF adalah penentu apa suatu sistem dipercayai lebih bermanfaat, lebih penting/relatif memberikan keuntungan. Pengaruh kinerja dalam hal ini berdampak pada perbaikan efisiensi, perbaikan efektivitas maupun peningkatan kualitas.

Menurut Hendrawati (2013:153) yang mengutip dari Godhue \& Thompson (1995), Model TTF merupakan suatu mode1 yang menitik beratkan pada tingkat kesesuaian dari kemampuan teknologi guna memenuhi kebutuhan tugas da1am pekerjaan, adalah kemampuan teknologi informasi memberikan dukungan terhadap pekerjaan. Berdasarkan teori TTF, sistem informasi akan dianggap memberikan peningkatan kinerja dari penggunanya apabila sistem tersebut memiliki kesesuaian (fit) yang baik dengan pekerjaan dari penggunanya. Model ini memiliki empat konstruk kunci diantaranya: Task Characteristic, Technology Characteristic, yang bersama-sama mempengaruhi konstruk TTF, serta konstruk (TTF) dapat mempengaruhi variabel performance dan atau utilization.

Dalam jogiyanto (2008:537) pengukuran dalam TTF terdiri dari:

1. Quality (Kualitas)

Dalam goodhue and Thompson (1995:222) dimensi qualitas terdiri dari :

a. Currency of the data (keterkinian/ pemutakhiran data);

b. Right data is maintained (kebenaran data);

c. Right level of detail (detail level kebenaran).

2. Locatability (lokatabilitas)

Dalam goodhue and Thompson (1995:222)

dimensi qualitas terdiri dari :

a. Locatability (penempatan);

b. Meaning of data is easy to find out (arti data mudah ditemukan).
3. Authorization (Otorisasi)

Yang dimaksud otorisasi disini adalah hak akses, yaitu hak yang dimiliki oleh operator terhadap sistem yang ada sesuai dengan pekerjaannya.

4. Compatibility (Kompatibilitas)

Yang dimaksud dengan kompatibilitas adalah adanya kesesuaian data antara riil dengan data yang diinputkan pada sistem.

Dikutip dalam Jogiyanto (2008:325) "The degree to which an innovation is perceived as being consistent with the existing value, needs and past experiences of potential adopters" (Moore and Benbasat, 1991) yaitu sejauh mana suatu inovasi dianggap konsisten dengan nilai yang ada, kebutuhan dan pengalaman masa lalu dari pengadopsi potensial.

itemnya adalah sebagai berikut :

a. "Using the system is compatible with all aspects of my work", bahwa menggunakan sistem yang ada telah sesuai dengan pekerjaan pengguna;

b. "I think that using the system fits well with the way I like to work", bahwa pengguna beranggapan menggunakan sistem yang sesuai dengan cara yang disukai untuk menyelesaikan tugass;

c. "Using the system fits into my work style", bahwa menggunakan sistem dirasakan sesuai dengan gaya bekerja pengguna.

5. Ease of Use (Kemudahan Penggunaan)

Kemudahanpenggunaan meruapakan asumsi yang muncul dari adanya persepsi kemudahanpenggunaan (perceived ease of use) yaitu "The degree to which an individual believes that using a particular system would be free of effort (adapted from Davis, 1986)" dikutip dalam Goodrum 2016:102. yaitu sejauh mana seseorang mempercayai bahwa dengan menggunakan suatu sistem tertentu dapat terbebas dari usaha/ kesulitan.

Sedangkan Jogiyanto (2008:320) menyatakan bahwa "the degree to which using an innovation is perceived as being difficult to use", maksudnya adalah seberapa jaub menggunakan suatu inovasi dipersepsikan sebagai suatu hal yang sulit digunakan.

Item-itemnya yaitu:

a. "My interaction with the system is clear and understandable" (yaitu interaksi pengguna dengan sistem jelas serta bisa dipahami); 
b. "I believe that it is easy to get the system to do what I want it to do" (bahwa pengguna percaya bahwa mudah untuk membuat sistem melakukan yang ingin saya lakukan);

c. "Overall, I believe that the systeem is easy to use" (bahwa secara keseluruhan, pengguna percaya bahwa sistem ini mudah digunakan);

d. "Learning to operate the system is easy for me" (bahwa pengguna merasakan kemudahan dalam belajar mengoperasikan sistem).

6. Production Timeliness (Ketepatan waktu) Yaitu waktu yang dipergunakan untuk menyelesaiakan tugas harus sesuai dengan yang telah ditetapkan/ ditargetkan.

7. System Reliability (Keandalan Sistem) Adalah suatu tingkat kepercaayaan terhadap suatu sistem.

8. Relationship with User (Hubungan dengan pengguna lain)

Dalam Susanti (2006:29) dan Goodhue \& Thompson (1995:222) hubungan dengan pengguna lain terdiri dari lima dimensi yaitu:

a. "IS understanding of business" yaitu pemahaman bisnis oleh sistem informasi;

b. "IS interest and dedication" yaitu minat/ kepentingan system;

c. "Responsiveness" yaitu tingkat respon;

d. "Delivering agreed-upon solutions" yaitu dapat memberikan solusi yang disetujui;

e. "Technical and business planning assistance" yaitu bantuan perencanan teknis dan Bisnis.

Menurut "Goodhue, 1997:451 yang dikutip oleh Goodrum, 2016:38 a single individual engaged in a portfolio of tasks, utilization becomes the percentage of her portfolio of tasks for which an individual chooses to use the technology" dan menurut "Goodhue, 1995 dikutip dalam Goodrum, 2016:38 Also operationalized as overall dependence on systems". Seorang individu yang terlibat dalam portofolio tugas, pemanfaatan menjadi persentase portofolio tugasnya yang dipilih oleh individu untuk menggunakan teknologi serta dioperasionalkan sebagai ketergantungan menyeluruh terhadap sistem.

Dalam Jogiyanto (2008) pemanfaatan (utilization) terdiridari:

1) Konsekuensi yang di harapkan dari pemanfaatan (expected consequences of utilization) atau kepercayaan-kepercayaan (beliefs);

"Beliefs about the consequences of use" (Goodhue \& Thompson, 1995:218 dikutip oleh Goodrum, 2016:38 ) yaitu mempercayai tentang konsekuensi/ akibat dari penggunaan

2) Mempengaruhi Penggunaan (Affect toward using);

"Feelings about the consequences of using a system" (Staples \& Seddon, 2004:21 dikutip oleh Goodrum, 2016:38 ) yaitu perasaan tentang konsekuensi dari penggunaan sistem, yang terdiri dari

a. The System makes woork more interesting (Sistem membuat pekerjaan lebih menarik);

b. Working with the system is fun (Bekerja dengan sistem menyenangkan);

c. The system is okay for some jobs, but not the kind of job I want (Sistem tidak bermasalah untuk pekerjaan yang sama, tapi bukan pekerjaan yang pengguna inginkan),(Jogiyanto, 2008:327);

3) Norma-norma Sosial (Social Norms)

'A person's perception that most people who are important to him think he should or should not perform the behavior in question (Fishbein and Ajzen 1975:302 dikutip oleh Goodrum, 2016:38)" yaitu persepsi seseorang bahwa kebanyakan orang yang penting baginya berpikir dia harus atau tidak seharusnya melakukan perilaku yang dipertanyakan.

4) Kebiasaan (Habit)

"A habit is an action that has been done many times and has become automatic. That is, it is done without conscious thought (Ronis, Yates, and Kirscht, 1989 dikutip oleh Goodrum, 2016:38)" yaitu Kebiasaan adalah tindakan yang telah dilakukan berkali-kali dan menjadi otomatis jadi, hal tersebut dilakukan tanpa pikiran sadar/ reflex.

5) Kondisi yang memfasilitasi (Facilitating Conditions)

"Situational factors or constraints" (Goodhue, Littlefield, \& Straub, 1997 dikutip oleh Goodrum, 2016:38), merupakan faktor atau kendala situasional.

"Objective factors in the environment that observers agree make an act easy to do including the provision of computer support" (Jogiyanto (2008:325) yaitu faktor-faktor obyektif di lingkungan yang mana pengamat setuju membuat suatu tindakan untuk mudah 
dilakukan termasuk penyediaan dukungan komputer, itemnya adalah:

a. Guidance was available to me in the selection of the system (ketersediaan panduan bagi pengguna dalam pemilihan sistem);

b. Specialized instruction concerning the system was availble to me (adanya intruksi/ perintah khusus bagi tentang sistem pengguna);

c. A specific person (or group) is availabel for assistance with system difficulties (adanya seseorang/ grup tertentu untuk memberikan bantuan jika menghadapi kesulitan dengan sistem).

Dalam Goodhue dan Thompson (1995:213) "dampak kinerja berkaitan dengan tugas/ pekerjaan seorang individu dimana kinerj ayang lebih tinggi menunjukkan kombinasi peningkatan efisiensi, efektivitas danatau kualitas yang lebih baik. Tidak hanya TTF tinggi yang meningkatkan kemungkinan pemanfaatan tetapi juga meningkatkan dampak kinerja sistem serta sistem dengan TTF tinggi akan menuju pada kinerja yang lebih baik karena berhubungan dengan pemenuhan kebutuhan tugas individu."

Jogiyanto (2008:536) menyatakan dampak kinerja (performance impact) diukur menggunakan pengukuran persepsi sebab pengukuran kinerja yang obyektif tidak tersedia di lapangan dan tiap pengukuran bisa tidak sesuai dengan individu dengan tugass-tugas yang berbeda. Oleh karena itu terdapat tiga indikator yang dipakai dalam penelitian ini sesuai persepsi individu terhadap dampak persepsi sistem komputer dan pelayanan yaitu efektivitas, produktivitas dan kinerja.

\section{METODE PENELITIAN}

Penelitian ini menggunakan metode pendekatan kuantitatif dengan analisis Regresi dan Structural Equational Model, dimana setiap responden menjawab kuesioner yang telah diberikan yang berisikan pertanyaan dengan tipe jawaban tertutup menggunakan lima skala Likert. Populasi pengguna SIAKAD dan UB Feeder di FIA UB adalah:

Tabel 1. Populasi Operator SIAKAD sekaligus UB Feeder di UB

\begin{tabular}{|l|l|c|c|}
\hline No & \multicolumn{1}{|c|}{ Fakultas } & Jumlah & \% \\
\hline 1 & Hukum & 10 & 7.58 \\
\hline 2 & Ekonomi dan Bisnis & 8 & 6.06 \\
\hline 3 & $\begin{array}{l}\text { Ilmu Administrasi, } \\
\text { Vokasi dan UB Kediri }\end{array}$ & $13,5,2=20$ & 15.15 \\
\hline
\end{tabular}

\begin{tabular}{|l|l|c|c|}
\hline No & \multicolumn{1}{|c|}{ Fakultas } & Jumlah & $\%$ \\
\hline 4 & Pertanian & 5 & 3.79 \\
\hline 5 & Peternakan & 3 & 2.27 \\
\hline 6 & Teknik & 10 & 7.58 \\
\hline 7 & Kedokteran & 30 & 22.73 \\
\hline 8 & $\begin{array}{l}\text { Perikanan dan Ilmu } \\
\text { Kelautan }\end{array}$ & 7 & 5.30 \\
\hline 9 & $\begin{array}{l}\text { Matematika dan Ilmu } \\
\text { Pengetahuan }\end{array}$ & 6 & 4.55 \\
\hline 10 & Teknologi Pertanian & 8 & 6.06 \\
\hline 11 & $\begin{array}{l}\text { Ilmu Sosial dan Ilmu } \\
\text { Politik }\end{array}$ & 8 & 6.06 \\
\hline 12 & Ilmu Budaya & 4 & 3.03 \\
\hline 13 & Kedokteran Hewan & 4 & 3.03 \\
\hline 14 & Ilmu Komputer & 6 & 4.55 \\
\hline 15 & Kedokteran Gigi & 2 & 1.52 \\
\hline 16 & Pascasarjana & 1 & 0.76 \\
\hline & Jumlah & 132 & 100 \\
\hline
\end{tabular}

Jumlah operator disetiap fakultas berbedabeda sehingga digunakan pengambilan sampel secara stratified random sampling dan secara terinci dapat dilihat pada:

Tabel 2. Sampel Operator SIAKAD sekaligus UB Feeder di UB

\begin{tabular}{|l|l|c|c|}
\hline No & \multicolumn{1}{|c|}{ Fakultas } & Jumlah & \% \\
\hline 1 & Hukum & 8 & 7 \\
\hline 2 & Ekonomi dan Bisnis & 6 & 5 \\
\hline 3 & $\begin{array}{l}\text { Ilmu Administrasi, } \\
\text { Vokasi dan UB Kediri }\end{array}$ & 15 & 24 \\
\hline 4 & Pertanian & 4 & 3 \\
\hline 5 & Peternakan & 2 & 2 \\
\hline 6 & Teknik & 8 & 8 \\
\hline 7 & Kedokteran & 23 & 6 \\
\hline 8 & $\begin{array}{l}\text { Perikanan dan Ilmu } \\
\text { Kelautan }\end{array}$ & 5 & 15 \\
\hline 9 & $\begin{array}{l}\text { Matematika dan Ilmu } \\
\text { Pengetahuan }\end{array}$ & 4 & 4 \\
\hline 10 & Teknologi Pertanian & 6 & 2 \\
\hline 11 & $\begin{array}{l}\text { Ilmu Sosial dan Ilmu } \\
\text { Politik }\end{array}$ & 6 & 8 \\
\hline 12 & Ilmu Budaya & 3 & 23 \\
\hline 13 & Kedokteran Hewan & 3 & 5 \\
\hline 14 & Ilmu Komputer & 4 & 5 \\
\hline 15 & Kedokteran Gigi & 1 & 6 \\
\hline 16 & Pascasarjana & 99 & 100 \\
\hline & Jumlah & & 6 \\
\hline
\end{tabular}

Model TPC menggambarkan pentingnya peran teknologi terhadap dampak kinerja pada tingkat individual. Model ini bertujuan supaya TI bisa memberi dampak positif terhadap kinerja individual maka teknologi harus sesuai dan bisa dimanfaatkan sesuai jenis pekerjaan. Variabel yang di pakai di dalam penelitian ini guna menganalisis pengaruh TTF dan pemanfaatan Siakad dan UB-Feeder terhadap dampak kinerja individu yaitu karakteristik tugas, karakteristik teknologi, kesesuaian tugas-teknologi dan pemanfaatan Siakad sekaligus UB Feeder, serta kinerja individual. 
Kerangka di penelitian ini:

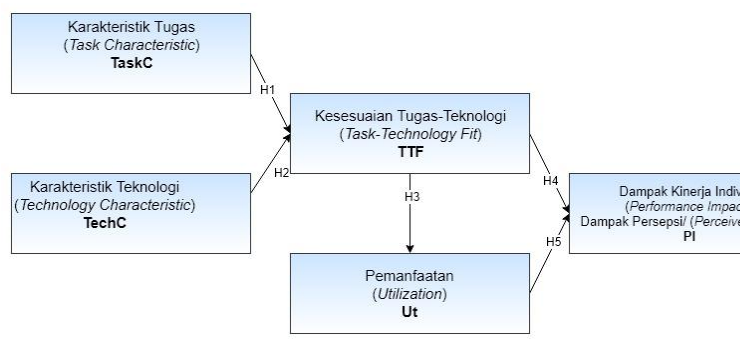

Gambar 2. Kerangka Penelitian

Hipotesis di penelitian ini:

Tabel 3. Hipotesis Penelitian

\begin{tabular}{|c|l|}
\hline H & \multicolumn{1}{|c|}{ Hipotesis } \\
\hline H1 & $\begin{array}{l}\text { Karakteristik Tugas (Task Characteristic/ TaskC) } \\
\text { berpengaruh terhadap Kesesuaian Tugas- } \\
\text { Teknologi (Task-Technology Fit/ TTF) }\end{array}$ \\
\hline H2 & $\begin{array}{l}\text { Karakteristik Teknologi (Technology } \\
\text { Characteristic/ TechC) berpengaruh terhadap } \\
\text { Kesesuaian Tugas-Teknologi (Task-Technology } \\
\text { Fit/ TTF) }\end{array}$ \\
\hline H3 & $\begin{array}{l}\text { Kesesuaian Tugas-Teknologi (Task-Technology } \\
\text { Fit/ TTF) berpengaruh terhadap Pemanfaatan } \\
\text { (Utilization/ Ut) }\end{array}$ \\
\hline H4 & $\begin{array}{l}\text { Kesesuaian Tugas-Teknologi (Task-Technology } \\
\text { Fit/ TTF) berpengaruh terhadap Dampak Kinerja } \\
\text { Individu (Performance Impact/ PI) }\end{array}$ \\
\hline H5 & $\begin{array}{l}\text { Pemanfaatan (Utilization/ Ut) berpengaruh } \\
\text { terhadap Dampak Kinerja (Performance Impact/ } \\
\text { PI) }\end{array}$ \\
\hline
\end{tabular}

Indikator untuk setiap variabel dalam penelitian adalah:

1. Variabel Karakteristik Tugas/Task

Characteristic/ TaskC, indikatornya;

a. Tidak Rutin/Non-Routineness; (TaskC.1)

b. Saling Ketergantungan/Interdependence; (TaskC.2)

c. Titel Pekerjaan/Job Title; (TaskC.3)

2. Variabel Karakteristik Teknologi /Technology Characteristic/TechC;

a. Sistem lnformasi Tertentu yang Dipergunakan/Particular System Used; (TechC.1)

b. Departemen/Bagian/Department; (TechC.2.)

3. Variabel Kesesuaian Tugas-Teknologi/TaskTechnology Fit/TTF;

a. Quality (Kualitas); (TTF.1.), terdiri dari Currency of the data, Right data is maintained dan Right level of detail;

b. Locatability (lokatabilitas); (TTF.2), terdiri dari Locatability dan Meaning of data is easy to find out;

c. Authorization (Otorisasi); (TTF.3.), bahwa hak akses yang dimiliki oleh operator terhadap sistem yang ada sesuai dengan pekerjaannya;

d. Compatibility (Kompatibilitas: kesesuaian data); (TTF.4.), yaitu sejauh mana suatu inovasi dianggap konsisten dengan nilai yang ada, kebutuhan dan pengalaman masa lalu dari pengadopsi potensial;

e. Ease of Use (Kemudahan Penggunaan); (TTF.5.), yaitu sejauh mana seseorang percaya dengan menggunakan suatu sistem tertentu dapat terbebas dari usaha/ kesulitan;

f. Production Timeliness (Ketepatan waktu Produksi); (TTF.6)

g. System Reliability (Keandalan Sistem); (TTF.7)

h. Relationship with User (Hubungan dengan pengguna lain);(TTF.8).

4. Pemanfaatan/Utilization/ Ut

a. Konsekuensi yang diharapkan dari pemanfaatan/expected consequences of utilization atau kepercayaankepercayaan/beliefs; (Ut.1)

b. Mempengaruhi Penggunaan/Affect toward using; (Ut.2)

c. Norma-norma Sosial/Social Norms; (Ut.3)

d. Kebiasaan/Habit; (Ut.4)

e. Kondisi yang memfasilitasi/Facilitating Conditions; (Ut.5)

5. Dampak Kinerja (Performance Impact/ PI)
a. Efektivitas (PI.1)
b. Produktivitas (PI.2.)
c. Kinerja (PI.3.)

Dalam penelitian ini dilakukan proses uji:

1. Uji Instrumen meliputi:

a. Uji Validitas;

b. Uji Reliabilitas.

2. Analisis Statistik Deskriptif;

3. Analisis SEM PLS:
a. Pengujian Model Pengukuran (Measurement Model);
b. Pengujian Model Struktural (Structural Model). 
Berikut ini model analisis dengan outer loading $>0.7$ :

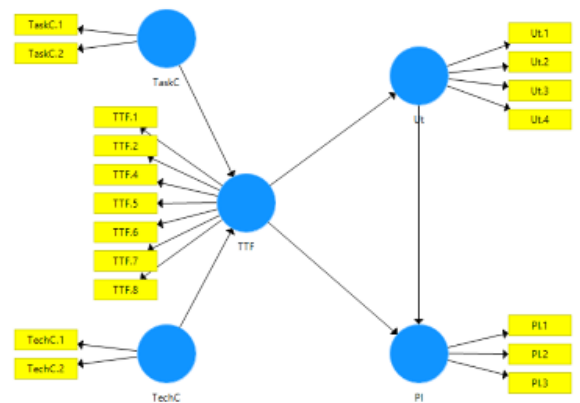

Gambar 3. Model Analisis dengan outer loading $>0.7$

\section{HASIL DAN PEMBAHASAN}

Berdasarkan analisis diperoleh hasil :

\subsection{Uji Instrumen}

\subsubsection{Uji Validitas}

Berdasarkan pada tabel $r$ product moment dengan signifikansi 5\% untuk jumlah $\mathrm{N}$ sebesar 99, nilai r adalah 0.196 .

Tabel 4. Ringkasan Hasil Uji Validitas

\begin{tabular}{|c|c|c|}
\hline Variabel & $\mathrm{r}$ & Kesimpulan \\
\hline TTF & r hitung $>0.196$ & Valid \\
\hline Ut & r hitung $>0.196$ & Valid \\
\hline PI & r hitung $>0.196$ & Valid \\
\hline TaskC & r hitung $>0.196$ & Valid \\
\hline TechC & r hitung $>0.196$ & Valid \\
\hline
\end{tabular}

Dari hasil analisis diketahui:

1. TaskC, 6 item dari variabel TaskC adalah valid karena nilainya berada diatas 0.196 sehingga dapat diikutsertakan dalam pengambilan sampel berikutnya;

2. TechC, bahwa 4 item dari variabel TechC adalah valid karena nilainya berada diatas 0.196 sehingga dapat diikutsertakan dalam pengambilan sampel berikutnya;

3. TTF, bahwa 44 item dari variabel TTF adalah valid karena nilainya berada diatas 0.196 sehingga dapat diikutsertakan dalam pengambilan sampel berikutnya;

4. Ut, 25 item dari variabel $\mathrm{Ut}$ adalah valid karena nilainya berada diatas 0.196 sehingga dapat diikutsertakan dalam pengambilan sampel berikutnya;

5. PI, bahwa 47 item dari variabel PI adalah valid karena nilainya berada diatas 0.196 sehingga dapat diikutsertakan dalam pengambilan sampel berikutnya.

\subsubsection{Uji Reliabilitas}

Untuk mengukur suatu intrumen memiliki reliabilitas agar hasilnya dapat diandalkan sebagai bahan analisis menggunakan nilai
Cronbach's Alpha > 0.6. Dari uji instrumen diperoleh hasil:

Tabel 5. Ringkasan Hasil Uji Reliabilitas

\begin{tabular}{|c|c|c|c|}
\hline Variabel & Cronbac's Alpha & $\mathrm{N}$ & Kriteria \\
\hline TTF & 0.959 & 44 & Sangat Tinggi \\
\hline Ut & 0.918 & 24 & Sangat Tinggi \\
\hline PI & 0.971 & 47 & Sangat Tinggi \\
\hline TaskC & 0.738 & 6 & Tinggi \\
\hline TechC & 0.859 & 4 & Tinggi \\
\hline
\end{tabular}

\subsection{Analisis Statistik Deskriptif}

Penelitian ini melibatkan lima variabel yaitu Karakteristik Tugas (Task Characteristic/TaskC), Karakteristik Teknologi (Technology Characteristic/TechC), Kesesuaian Tugas Teknology (Task-Technology Fit / TTF), Pemanfaatan (Utilization/Ut) dan Dampak Kinerja Individu (Performance Impact/PI). Analisis statistika deskriptif digambarkan dalam prosentase, nilai rata-rata dari setiap item dan indikator serta variabel. Deskripsi ini dapat memberikan penilaian pada kelima variabel penelitian. Berikut ini hasil perhitungan analisis deskriptif menggunkana SPSS;

Tabel 6. Rata-rata Jawaba Responden tiap Indikator

\begin{tabular}{|c|c|c|c|}
\hline Var & Indikator & $\begin{array}{l}\text { Rata- } \\
\text { rata } \\
\text { indikat } \\
\text { or }\end{array}$ & Rerata \\
\hline \multirow[t]{8}{*}{ TTF } & TTF.1 & 4.29 & 4.12 \\
\hline & TTF.2 & 4.19 & \\
\hline & TTF.3 & 3.70 & \\
\hline & TTF.4 & 4.15 & \\
\hline & TTF.5 & 4.08 & \\
\hline & TTF.6 & 4.20 & \\
\hline & TTF.7 & 4.17 & \\
\hline & TTF.8 & 4.13 & \\
\hline \multirow[t]{5}{*}{ Ut } & Ut.1 & 4.11 & 4.03 \\
\hline & Ut. 2 & 3.96 & \\
\hline & Ut.3 & 4.02 & \\
\hline & Ut.4 & 4.01 & \\
\hline & Ut.5 & 4.03 & \\
\hline \multirow[t]{3}{*}{ PI } & PI.1 & 4.12 & 4.12 \\
\hline & PI.2 & 4.21 & \\
\hline & PI.3 & 4.11 & \\
\hline \multirow{3}{*}{$\begin{array}{l}\text { Task } \\
\text { Character } \\
\text { istic } \\
\text { (TaskC) }\end{array}$} & TaskC.1 & 3.69 & 3.76 \\
\hline & TaskC.2 & 3.94 & \\
\hline & TaskC.3 & 3.65 & \\
\hline \multirow{2}{*}{$\begin{array}{l}\text { Technolog } \\
y \\
\text { Character } \\
\text { istic } \\
\text { (TechC) }\end{array}$} & Tech.1 & 4.20 & 4.17 \\
\hline & Tech.2 & 4.14 & \\
\hline
\end{tabular}




\subsection{Analisis Statistik Inferensial/Evaluasi} Model

\subsubsection{Pengujian Model Pengukuran (Measurement Model)}

4.3.1.1. Validitas Konvergensi (Convergent Validity)

Validitas konvergensi berhubungan dengan prinsip bahwa pengukur suatu konstruk harus memiliki korelasi tinggi. Uji validitas konvergensi yang diukur menggunakan PLS dinilai berdasarkan loading factor indikator untuk masing-masing konstruk, jadi semakin tinggi nilai loading faktor maka semakin penting peranan loading dalam menginterpretasikan matrik faktor.

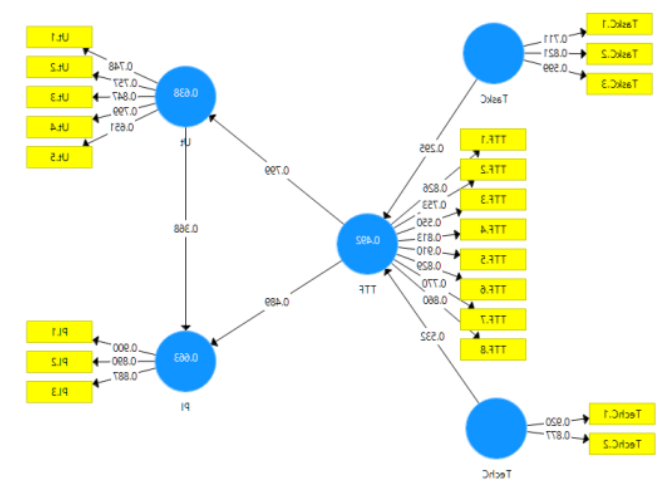

Gambar 4. Diagram Jalur Hasil Analisis SEM

Agar dapat dikatakan valid tiap indikator harus memiliki outer loding lebih dari 0.7 oleh karena itu untuk indikator yang memiliki loading factor dengan nilai kurang dari 0.7 harus didrop dari analisis. Berdasarkan model penelitian awal pada gambar 3 diketahui terdapat tiga indikator yang memiliki nilai loading factor kurang dari 0.7 sehingga harus didrop dari analisis yaitu TTF.3, TaskC.3, dan Ut.5, sehingga berikut ini adalah hasil loading factor setelah proses drop tiga (3) variabel;

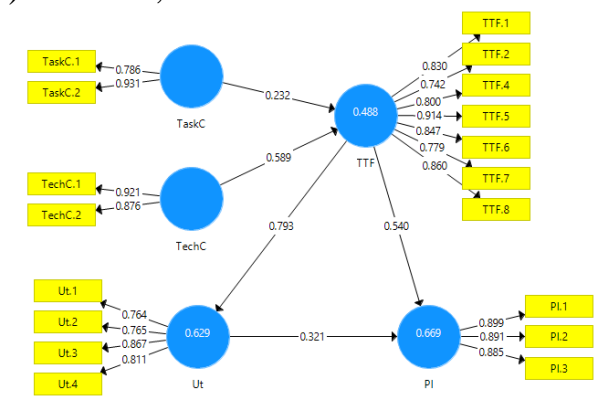

Gambar 5. Tampilan Output ModelPengukuran (Outer Model> 0.7)

\subsubsection{Validitas Diskriminan (Diskriminant Validity)}

Nilai korelasi indikator PI.1 terhadap variabel PI adalah 0.899 , nilai ini lebih besar daripada nilai korelasi PI.1 terhadap TTF
(0.768), TaskC (0.385), TechC (0.742) dan Ut (0.778). Nilai korelasi indikator PI.2 terhadap PI sebesar 0.891, nilai ini lebih besar daripada nilai korelasi PI.2 terhadap TTF (0.674), TaskC (0.221), TechC (0.541) dan Ut (0.572). Begitu juga pada nilai korelasi PI.3 terhadap PI yang nilainya lebih besar daripada PI.3 terhadap TTF, TaskC, TechC dan Ut.

Nilai korelasi indikator TTF.1 terhadap variabel TTF sebesar 0.830 , nilainya lebih besar dari nilai korelasi TTF.1 terhadap PI (0.580), TaskC (0.350), TechC (0.468) dan Ut (0.537). Nilai korelasi indikator TTF. 2 terhadap variabel TTF sebesar 0.742 , nilai ini lebih besar daripada nilai korelasi TTF.2 terhadap PI (0.554), TaskC (0.355), TechC (0.384) dan Ut (0.554). Begitu juga pada nilai korelasi TTF.3, TTF.4, TTF.5, TT.6, TTF.7 dan TTF.8 terhadap PI yang nilainya lebih besar daripada TTF.3, TTF.4, TTF.5, TT.6, TTF.7 dan TTF.8 terhadap PI, TaskC, TechC dan Ut.

Nilai korelasi indikator TaskC.1 terhadap TaskC sebesar 0.786, nilai ini lebih besar daripada nilai korelasi TaskC.1 terhadap PI (0.210), TTF (0.257), TechC (0.168) dan Ut (0.281). Nilai korelasi TaskC.2 terhadap variabel TaskC sebesar 0.931, nilai ini lebih besar daripada nilai TaskC.2 terhadap PI (0.264), TTF (0.435), TechC (0.347) dan Ut (0.421).

Nilai korelasi TechC.1 terhadap TechC sebesar 0.921, nilai ini lebih bear daripada nilai korelasi TechC. 1 terhadap variabel PI (0.676), TTF (0.652), TaskC (0.276) dan Ut (0.590). Untuk nilai korelasi TechC.2 terhadap variabel TechC sebesar 0.876 , nilai korelasi ini lebih besar daripada nilai korelasi TechC.2 terhadap variabel PI (0.580), TTF (0.529) TaskC (0.3030) dan Ut (0.547).

Sedangkan nilai korelasi Ut.1 terhadap variabel UT adalah sebesar 0.764 , nilai ini lebih besar daripada nilai korelasi Ut.1 terhadap variabel PI (0.676), TTF (0.695), TaskC (0.396) dan Tech C (0.440). nilai korelasi Ut.2 terhadap variabel Ut sebesar 0.765 , nilai ini lebih besar daripada nilai korelasi Ut.2 terhadap variabel PI (0.523), TTF (0.605), TaskC (0.301), dan TechC (0.452). Begitu juga pada nilai korelasi Ut.3 dan Ut.4, terhadap Ut yang nilainya lebih besar daripada Ut.3 dan Ut.4, terhadap PI, TTF, TaskC, TechC.

Data tersebut diatas menunjukkan bahwa konstruk laten mampu memprediksi ukuran pada bloknya sendiri secara lebih baik daripada blok yang lainnya. Dengan demikian dapat disimpulkan bahwa pengukur/ indikator yang 
dipergunakan dalam penelitian ini telah memenuhi validitas diskriminan yang baik.

\subsubsection{Reliabilitas Konstruk}

Pengujian konstruk dapat dilihat di nilai Cronbach's Alpha juga Composite Reliability. Cronbach's Alpha dipakain untuk mengukur batas bawah nilai reliabilitas konstruk dan untuk Composite Reliability digunakan untuk mengukur nilai sesungguhnya reliabiitas suatu konstruk. Pada penelitian ini melakukan uji reliabilitas dengan menggunakan Composite Reliability sebab hasilnya lebih bagus dalam mengestimasi konsistensi internal suatu konstruk.

Tabel 7. Construct Reliability dan Validity

\begin{tabular}{|c|c|c|c|c|}
\hline Var & $\begin{array}{c}\text { Cronbach's } \\
\text { Alpha }\end{array}$ & rho_A & $\begin{array}{c}\text { Reliabiltas } \\
\text { Komposit }\end{array}$ & $\begin{array}{c}\text { Rata-rata } \\
\text { Varians } \\
\text { Diekstrak } \\
\text { (AVE) }\end{array}$ \\
\hline PI & 0.872 & 0.881 & 0.921 & 0.975 \\
\hline TTF & 0.922 & 0.930 & 0.938 & 0.683 \\
\hline TaskC & 0.672 & 0.801 & 0.851 & 0.742 \\
\hline TechC & 0.764 & 0.788 & 0.894 & 0.808 \\
\hline Ut & 0.815 & 0.817 & 0.879 & 0.645 \\
\hline
\end{tabular}

Dengan memakai Composite Reliability dilakukan evaluasi model pengukuran dengan tujuan guna menentukan suatu konstruk/variabel punya reliabilitas yang tinggi atau tidak. Apabila nilai Composite Reliability >0.6 maka suatu konstruk dinyatakan reliabel.

\subsubsection{Model Pengukuran Variabel Karakteristik Tugas/TaskC}

Variabel ini terukur oleh tiga indikator yaitu Non routineness (TaskC.1) dan Interdependence (TaskC.2).

Tabel 8. Model Pengukuran Variabel TaskC

\begin{tabular}{|l|l|l|l|}
\hline \multicolumn{1}{|c|}{ Indikator } & $\begin{array}{c}\text { Loading } \\
\text { Factor }\end{array}$ & $\begin{array}{c}P \text { - } \\
\text { value }\end{array}$ & Kesimpulan \\
\hline $\begin{array}{l}\text { Non routineness } \\
\text { (TaskC.1) }\end{array}$ & 0.786 & 0.000 & Signifikan \\
\hline $\begin{array}{l}\text { Interdependence } \\
\text { (TaskC.2) }\end{array}$ & 0.931 & 0.000 & Signifikan \\
\hline AVE & \multicolumn{3}{|c|}{0.742} \\
\hline $\begin{array}{l}\text { Composite } \\
\text { Reliability }\end{array}$ & \multicolumn{3}{|c|}{0.851} \\
\hline
\end{tabular}

Jika nilai p-value $<0.005$ maka signifikan. Kedua indikator yaitu Non routineness (TaskC.1) dan Interdependence (TaskC.2), signifikan sebagai pengukur Karakteristik Tugas (Task Characteristicl TaskC). Dari besarnya koefisien loading factor tertinggi diperoleh bahwa Interdependence (TaskC.2) sebagai pengukur terkuat Karakteristik Tugas, artinya, Karakteristik Tugas (Task Characteristicl TaskC), utamanya terlihat dari tinggi Interdependence (TaskC.2). Pada Tabel 7 nampak nilai AVE sebesar 0.742 dan nilai composite reliability sebesar 0.851 yang telah memenuhi syarat pengukuran.

\subsubsection{Model Pengukuran Variabel Karakteristik Teknologi/TechC}

Pada bagian kedua disajikan model pengukuran variabel Karakteristik Teknologi yang terukur oleh dua indikator yaitu Particular System Use (TechC.1) dan Department (TechC.2).

Tabel 8. Model Pengukuran Variabel TechC

\begin{tabular}{|l|l|l|l|}
\hline \multicolumn{1}{|c|}{ Indikator } & $\begin{array}{c}\text { Loading } \\
\text { Factor }\end{array}$ & P-value & Kesimpulan \\
\hline $\begin{array}{l}\text { Particular System } \\
\text { Use (TechC.1) }\end{array}$ & 0.921 & 0.000 & Signifikan \\
\hline $\begin{array}{l}\text { Department } \\
\text { (TechC.2) }\end{array}$ & 0.876 & 0.000 & Signifikan \\
\hline AVE & \multicolumn{3}{|c|}{0.808} \\
\hline $\begin{array}{l}\text { Composite } \\
\text { Reliability }\end{array}$ & \multicolumn{3}{|c|}{0.894} \\
\hline
\end{tabular}

Kedua indikator yaitu Particular System Use (TechC.1) dan Department (TechC.2) dengan koefisien loading factor tertinggi pada Particular System Use (TechC.1) sebagai pengukur terkuat Karakteristik Teknologi/Technology Characteristic/TechC. Berarti Karakteristik Teknologi /Technology Characteristic /TechC terlihat dari tingginya Particular System Use (TechC.1). Pada Tabel 7 nilai AVE sebesar 0.808 dan nilai composite reliability sebesar 0.894 yang telah memenuhi syarat pengukuran.

\subsubsection{Model Pengukuran Variabel Kesesuaian Tugas Teknologi/TTF}

Bagian ketiga disajikan model pengukuran variabel Kesesuaian Tugas Teknologi yang terukur oleh tujuh indikator yaitu Quality (TTF.1), Locatability (TTF.2), Compatibility (TTF.4), Easy of Use (TTF.5), Production Timeliness (TTF.6), System Reliability (TTF.7) dan Relationship with User (TTF.8).

Tabel 9. Model Pengukuran Variabel TTF

\begin{tabular}{|l|l|l|l|}
\hline \multicolumn{1}{|c|}{ Indikator } & $\begin{array}{c}\text { Loadin } \\
g \\
\text { Factor }\end{array}$ & $\begin{array}{c}\text { P- } \\
\text { value }\end{array}$ & Kesimpulan \\
\hline Quality (TTF.1) & 0.830 & 0.000 & Signifikan \\
\hline Locatability (TTF.2) & 0.742 & 0.000 & Signifikan \\
\hline $\begin{array}{l}\text { Compatibility } \\
\text { (TTF.4) }\end{array}$ & 0.800 & 0.000 & Signifikan \\
\hline Easy of Use (TTF.5) & 0.914 & 0.000 & Signifikan \\
\hline $\begin{array}{l}\text { Production } \\
\text { Timeliness (TTF.6) }\end{array}$ & 0.847 & 0.000 & Signifikan \\
\hline $\begin{array}{l}\text { System Reliability } \\
\text { (TTF.7) }\end{array}$ & 0.779 & 0.000 & Signifikan \\
\hline $\begin{array}{l}\text { Relationship with } \\
\text { User (TTF.8) }\end{array}$ & 0.860 & 0.000 & Signifikan \\
\hline AVE & \multicolumn{4}{|c|}{0.683} \\
\hline $\begin{array}{l}\text { Composite } \\
\text { Reliability }\end{array}$ & \multicolumn{4}{|c|}{} \\
\hline
\end{tabular}


Ketuju indikator yaitu Quality (TTF.1), Locatability (TTF.2), Compatibility (TTF.4), Easy of Use (TTF.5), Production Timeliness (TTF.6), System Reliability (TTF.7) dan Relationship with User (TTF.8) adalah signifikan merupakan pengukur Kesesuaian Tugas-Teknologi (Task-Technology Fit / TTF). Dari besarnya koefisien loading factor tertinggi diperoleh bahwa , Easy of Use (TTF.5) sebagai pengukur terkuat Kesesuaian Tugas-Teknologi (Task-Technology Fit/TTF). Artinya, Kesesuaian Tugas-Teknologi (Task-Technology Fit/ TTF) , utamanya terlihat dari tingginya nilai Easy of Use (TTF.5). Pada tabel 7 diatas juga diketahui nilai AVE sebesar 0.683 dan nilai composite reliability sebesar 0.938 yang telah memenuhi syarat pengukuran.

\subsubsection{Model Pengukuran Variabel Pemanfaatan/Ut}

Pada bagian keempat disajikan model pengukuran variabel Pemanfaatan (Utilization/ Ut) yang terukur oleh empat indikator yaitu Expected Consequnces of Utilization (Ut.1), Affect toward using (Ut.2), Social Norms (Ut.3) dan Habit (Ut.4).

Tabel 10. Model Pengukuran Variabel Ut

\begin{tabular}{|l|l|l|l|}
\hline \multicolumn{1}{|c|}{ Indikator } & $\begin{array}{c}\text { Loading } \\
\text { Factor }\end{array}$ & P-value & Kesimpulan \\
\hline $\begin{array}{l}\text { Expected Consequnces of } \\
\text { Utilization (Ut.1) }\end{array}$ & 0.764 & 0.000 & Signifikan \\
\hline $\begin{array}{l}\text { Affect toward using } \\
\text { (Ut.2) }\end{array}$ & 0.765 & 0.000 & Signifikan \\
\hline Social Norms (Ut.3) & 0.867 & 0.000 & Signifikan \\
\hline Habit (Ut.4) & 0.811 & 0.000 & Signifikan \\
\hline AVE & \multicolumn{3}{|c|}{0.645} \\
\hline Composite Reliability & \multicolumn{3}{|c|}{0.879} \\
\hline
\end{tabular}

Keempat indikator yaitu Expected Consequnces of Utilization (UT.1), Affect toward using (UT.2), Social Norms (UT.3), dan Habit (UT.4 signifikan sebagai pengukur Pemanfaatan (Utilization/ Ut). Dari besarnya koefisien loading factor tertinggi diperoleh bahwa Social Norms (UT.3) sebagai pengukur terkuat Pemanfaatan (Utilization/ Ut),berarti variabel Pemanfaatan (Utilization/ Ut) terutama terlihat dari tingginya indikasi Social Norms (UT.3). Pada Tabel 7 juga diketahui nilai AVE sebesar 0.645 dan nilai composite reliability sebesar 0.879 yang telah memenuhi syarat pengukuran.

\subsubsection{Model Pengukuran Variabel Dampak Kinerja Individu/PI}

Bagian kelima disajikan model pengukuran variabel Dampak Kinerja Individu (Performance Impact/PI) yang terukur oleh tiga indikator yaitu
Efektifitas (PI.1), Produktivitas (PI.2) dan Kinerja (PI.3).

Tabel 11. Model Pengukuran Variabel Dampak Kinerja Individu/PI

\begin{tabular}{|l|l|l|l|}
\hline \multicolumn{1}{|c|}{ Indikator } & $\begin{array}{c}\text { Loading } \\
\text { Factor }\end{array}$ & $\begin{array}{c}P \text { - } \\
\text { value }\end{array}$ & Kesimpulan \\
\hline Efektifitas (PI.1) & 0.899 & 0.000 & Signifikan \\
\hline Produktivitas (PI.2) & 0.891 & 0.000 & Signifikan \\
\hline Kinerja (PI.3) & 0.885 & 0.000 & Signifikan \\
\hline AVE & \multicolumn{3}{|c|}{0.795} \\
\hline Composite Reliability & \multicolumn{3}{|c|}{0.921} \\
\hline
\end{tabular}

Ketiga indikator yaitu Efektifitas (PI.1), Produktivitas (PI.2) dan Kinerja (PI.3), signifikan sebagai pengukur Dampak Kinerja Individu (Performance Impact/ PI) dengan koefisien loading factor tertinggi diperoleh bahwa Efektifitas (PI.1) sebagai pengukur terkuat Dampak Kinerja Individu (Performance Impact/ PI). Artinya, Dampak Kinerja Individu (Performance Impact/ PI) terlihat dari tingginya indikasi Efektifitas (PI.1). Pada Tabel 7 diketahui nilai AVE sebesar 0.795. Selain itu diperoleh juga nilai alpha cronbach sebesar 0.872 dan nilai composite reliability sebesar 0.921 yang telah memenuhi syarat pengukuran.

\subsubsection{Pengujian Model Struktural/Structural Model /Inner Model)}

Model ini menyajikan hubungan antar variabel penelitian Koefisien struktural model menyatakan besaran hubungan antara satu variabel terhadap variabel lain. Pengaruh yang signifikan antar variabel satu terhadap variabel lain, jika nilai $P$-value $<0.05$.

\section{Tabel 12. Pengaruh Langsung}

\begin{tabular}{|c|l|c|c|c|}
\hline No & \multicolumn{1}{|c|}{ Hubungan } & $\begin{array}{l}\text { Koe } \\
\text { fisien }\end{array}$ & P-value & Kesimpulan \\
\hline 1 & $\begin{array}{l}\text { Karakteristik Tugas (Task } \\
\text { Characteristic/TaskC) } \\
\text { terhadap Kesesuaian Tugas- } \\
\text { Teknologi (Task-Technology } \\
\text { Fit/TTF) }\end{array}$ & 0.232 & 0.004 & Signifikan \\
\hline 2 & $\begin{array}{l}\text { Karakteristik Teknologi (Technology } \\
\text { Characteristic/TechC) } \\
\text { terhadap Kesesuaian Tugas } \\
\text { Teknologi (Task-Technology Fit/ } \\
\text { TTF) }\end{array}$ & 0.589 & 0.000 & Signifikan \\
\hline 3 & $\begin{array}{l}\text { Kesesuaian Tugas-Teknologi (Task- } \\
\text { Technology Fit/TTF) } \\
\text { terhadap Pemanfaatan } \\
\text { (Utilization/Ut) }\end{array}$ & 0.793 & 0.000 & Signifikan \\
\hline 4 & $\begin{array}{l}\text { Kesesuaian Tugas-Teknologi (Task- } \\
\text { Technology Fit/TTF) } \\
\text { terhadap Dampak Kinerja Individu } \\
\text { (Performance Impact/PI) }\end{array}$ & 0.540 & 0.000 & Signifikan \\
\hline 5 & $\begin{array}{l}\text { Pemanfaatan (Utilization/Ut) } \\
\text { terhadap Dampak Kinerja Individu } \\
\text { (Performance Impact/PI) }\end{array}$ & 0.321 & 0.004 & Signifikan \\
\hline
\end{tabular}




\subsubsection{Pengaruh terhadap Kesesuaian Tugas Teknologi/TTF}

Diperoleh koefisien struktural sebesar 0.232, dan P-value 0.004. Karena P-value < 0.05 mengindikasikan ada pengaruh signifikan dan positif Karakteristik Tugas terhadap Kesesuaian Tugas-Teknologi. Koefisien bertanda positif mengindikasikan hubungan keduanya berbanding lurus, semakin tinggi Karakteristik Tugas, akan mengakibatkan semakin tinggi Kesesuaian Tugas-Teknologi dan sebaliknya.

\section{Hipotesis 1 penelitian ini diterima}

\subsubsection{Pengaruh Karakteristik Teknologi/ TechC terhadap Kesesuaian Tugas- Teknologi/TTF}

Diperoleh koefisien structural sebesar 0.589 , dan $\mathrm{P}$-value $=0.000$. Karena $\mathrm{P}$-value $<0.05$, koefisien bertanda positif menandakan ada pengaruh signifikan dan positif antara variabel karakteristik teknologi terhadap variabel kesesuaian tugas-teknologi. Koefisien bertanda positif mengindikasikan hubungan keduanya berbanding lurus dimana makin tinggi Karakteristik Teknologi mengakibatkan semakin tinggi pula Kesesuaian Tugas Teknologi.

\section{Hipotesis 2 penelitian ini diterima.}

\subsubsection{Pengaruh Kesesuaian Tugas- Teknologi/TTF terhadap Pemanfaatan/Ut}

Diperoleh koefisien structural sebesar 0.793 , dan $\mathrm{P}$-value $=0.000$, dengan besarnya $\mathrm{P}$ value $<0.05$, dan koefisien bertanda positif menandakan ada pengaruh signifikan serta positif antara Kesesuaian Tugas-Teknologi terhadap Pemanfaatan. Koefisien positif menandakan hubungan antara keduanya berbanding lurus, makin tinggi Kesesuaian Tugas-Teknologi maka makin tinggi Pemanfaatan.

\section{Hipotesis 3 penelitian ini diterima.}

\subsubsection{Pengaruh Kesesuaian Tugas/TTF terhadap Dampak Kinerja Individu/PI}

Didapatkan koefisien structural sebesar 0.540, dan P-value 0.000. Karena P-value < 0.05, serta koefisien bertanda positif mengindikasikan ada pengaruh signifikan dan positif antara Kesesuaian Tugas-Teknologi terhadap Dampak Kinerja. Koefisien positif mengindikasikan hubungannya berbanding lurus, jadi makin tinggi Kesesuaian Tugas-Teknologi akan mengakibatkan semakin tinggi pula Dampak Kinerja.
Hipotesis 4 penelitian ini diterima.

\subsubsection{Pengaruh Pemanfaatan/Ut terhadap Dampak Kinerja Individu/PI}

Diperoleh koefisien structural sebesar 0.321, dan P-value 0.004, dengan P-value < 0.05 dan koefisien bertanda positif mengindikasikan ada pengaruh signifikan dan positif antara Pemanfaatan terhadap Dampak Kinerja. Koefisien positif menandakan hubungan keduanya berbanding lurus, yaitu makin tinggi Kesesuaian Tugas akan mengakibatkan makin tinggi juga Dampak Kinerja.

\section{Hipotesis 5 penelitian ini diterima.}

\subsection{Pembahasan}

\subsubsection{Pengujian H1}

Pengujian H1 bertujuan mengetahui apakah terdapat pengaruh positif antara Karakteristik Tugas terhadap Kesesuaian Tugas-Teknologi. Dari hasil pengolahan data diperoleh nilai koefisien path antara Karakteristik Tugas dengan Kesesusaian Tugas-Teknologi sebesar 0.232 dan t-statistik 2.809. Nilai tersebut dibandingkan dengan nilai $t$ tabel dengan tingkat signifikan 0.05 dan jumlah responden 99 diperoleh $t$ tabel 1.66039, maka dinyatakan signifikan karena nilai t-statistik penelitian lebih besar dari t tabel.

Disimpulkan bahwa Karakteristik Tugas mempengaruhi Kesesuaian Tugas-Teknologi secara positif dan signifikan didukung secara statistik oleh data penelitian yang ada.

Hasil penelitian tersebut sejalan dengan penelitian Godhue \& Thompson (1995) yang menyatakan evaluasi pengguna terhadap TaskTechnology Fit dipengaruhi Task Characteristic serta dipengaruhi juga Technology Characteristic. Godhue \& Thompson melakukan penelitian terhadap dua model inti yaitu rantai TAM dan rantai TTF yang digabungkan menjadi TPC, yaitu salah satunya ditemukan terdapat hubungan yang signifikan antara TaskC terhadap TTF.

Besarnya nilai loading factor TaskC.2 (0.931) yaitu ketergantungan dengan rerata jawaban responden 3.94 lebih besar daripada nilai TaskC.1 (0.786) yaitu ketidakrutinan dengan rerata jawaban responden 3.69 yang mengindikasikan operator Siakad dan UB Feeder menunjukkan ketergantungan pada dua sistem tersebut, hal ini nampak nyata saat Siakad mengalami down (saat KRS dan input nilai) operator menjadi resah dan banyak melakukan komplain kepada TIK UB agar proses input yang dilakukan operator bisa kembali norma, hal ini 
berlaku juga pada UB Feeder yang terkadang mengalami down pada server tingkat universitas sehingga proses update maupun input data menjadi tersendat dan operator harus mengulang prosesnya.

Ketergantungan operator pada Siakad dan UB Feeder sesuai dengan tugas pekerjaannya yang membutuhkan kedua sistem tersebut karena operator merasa familiar dan mudah untuk menggunakannya. Hal ini nampak pada nilai loading faktor TTF.5 (0.914) yaitu kemudahan penggunaan dengan rerata jawaban responden sebesar 4.08 yang nilainya lebih besar daripada TTF.1 (kualitas; loading factor 0.830), TTF.2 (penempatan; loading factor 0.742), TTF.4 (kesesuaian; loading factor 0.800), TTF.6 (ketepatan waktu produksi; loading factor 0.847), TTF.7 (keandalan sistem; loading factor 0.779) dan TTF.8 (hubungan dengan pengguna lain; loading factor 0.860), ini menandakan bahwa saat operator merasakan kemudahan penggunaan Siakad dan UB Feeder maka membuat operator tetap menggunakan sistem tersebut karena memiliki kualitas yang dinterpretasikan oleh responden sangat tinggi (4.29)

Jadi semakin tinggi Karakteristik Tugas maka makin tinggi Kesesuaian TugasTeknologi. Kesesuaian Tugas-Teknologi sebagai faktor penting dalam keberhasilan operator dalam menyelesaikan tugas pekerjaannya. Jika tugas pekerjaannya diselesaikan dengan teknologi yang sesuai maka akan semakin efektif dan efisien

\subsubsection{Pengujian $\mathrm{H} 2$}

Pengujian $\mathrm{H} 2$ bertujuan mengetahui apakah terdapat pengaruh positif antara Karakteristik Teknologi terhadap Kesesuaian TugasTeknologi. Dari hasil olah data ditemukan nilai koefisien path antara Karakteristik Teknologi terhadap Kesesuaian Tugas-Teknologi sebesar 0.589 dan nilai t statistik sebesar 6.438, maka dinyatakan signifikan karena nilai t-statistik penelitian lebih besar dari $t$ tabel.

Jadi disimpulkan Karakteristik Teknologi mempengaruhi variabel kesesuaian TugasTeknologi secara positif dan signifikan didukung secara statistik oleh data penelitian yang ada.

Task Technology Fit akan dipengaruhi Task Characteristic serta dipengaruhi Technology Characteristic. Godhue \& Thompson melakukan penelitian terhadap dua model inti yaitu rantai TAM dan rantai TTF kemudian digabungk menjadi rantai TPC, dimana dalam penelitian tersebut ditemukan bahwa terdapat hubungan yang signifikan antara Karakteristik Teknologi (Technology Characteristic/ TechC) terhadap kesesuaian tugas-teknologi (Task-Technology Fit/TTF).

Besarnya nilai loading factor TechC.1 (0.921) yaitu sistem informasi tertentu dengan rerata jawaban responden 4.20 lebih besar daripada nilai TechC.2 (0.876) yaitu bagian/departemen/unit dengan rerata jawaban responden 4.14 yang mengindikasikan bahwa operator Siakad dan UB Feeder menggunakan dua sistem tersebut untuk menyelesaikan pekerjaannya sesuai tupoksi tiap responden. Hal ini nampak nyata saat operator memakai Siakad dan UB Feeder untuk meyelesaikan pekerjaannya karena sampai saat ini belum ada sistem serupa dengan Siakad maupun UB Feeder yang performanya bisa menggungguli dua sistem tersebut.

Ketergantungan operator terhadap Siakad dan UB Feeder sesuai dengan tugas kerjanya membutuhkan kedua sistem tersebut karena operator merasa terbiasa dan mudah menggunakannya. Hal ini nampak pada nilai loading faktor TTF.5 (0.914) yaitu kemudahan penggunaan dengan rerata jawaban responden sebesar 4.08 yang nilainya lebih besar daripada TTF.1 (kualitas; loading factor 0.830), TTF.2 (penempatan; loading factor 0.742), TTF.4 (kesesuaian; loading factor 0.800), TTF.6 (ketepatan waktu produksi; loading factor 0.847), TTF.7 (keandalan sistem; loading factor 0.779) dan TTF.8 (hubungan dengan pengguna lain; loading factor 0.860), ini menandakan bahwa saat operator merasakan kemudahan penggunaan Siakad dan UB Feeder maka membuat operator tetap mempergunakan sistem karena memiliki kualitas yang dinterpretasikan sangat tinggi (4.29) oleh responden.

Pada penelitian yang dilakukan di Universitas Brawijaya didapatkan bahwa semakin tinggi Karakteristik Teknologi maka akan makin tinggi juga Kesesuaian TugasTeknologi. Kesesuaian Tugas-Teknologi menjadi faktor penting menunjang keberhasilan pegawai dalam menyelesaikan tugas pekerjaannya. Jika tugas pekerjaannya diselesaikan dengan teknologi yang sesuai maka akan semakin efektif dan efisien.

\subsubsection{Pengujian $\mathrm{H3}$}

Pengujian $\mathrm{H} 3$ bertujuan untuk mengetahui apakah ada pengaruh positif Kesesuaian TugasTeknologi terhadap Pemanfaatan. Dari hasil olah 
data diperoleh koefisien path antara Kesesuaian Tugas-Teknologi terhadap Pemanfaatan sebesar 0.793 dan nilai t-statistik 14.044 dinyatakan signifikan karena nilai t-statistik penelitian lebih besar dari t tabel.

Jadi dapat disimpulkan bahwa Kesesuaian Tugas-Teknologi mempengaruhi Pemanfaatan secara positif dan signifikan didukung secara statistik oleh data penelitian yang ada.

Seperti halnya penelitian Joko Susilo (2016) dengan judul Analisis Faktor-faktor yang Mempengaruhi Pemanfaatan Teknologi Informasi dan Pengaruhnya terhadap Kinerja Karyawan PT Inalum (Persero) memakai model konseptual yang diajukan oleh Thompson et al (1991) untuk menguji faktor sosial, affect, kompleksitas, kesesuaian tugas-teknologi, konsekuensi jangka panjang juga kondisi yang memfasilitasi, juga memakai model konseptua Venkatesh et al., (2003) untuk menguji faktor minat pemanfaatan sistem teknologiinformasi, dan menggunakan model konseptual Lee et al., (2003) untuk menguji faktor dukungan manajemen dan menguji pemanfaatan TI terhadap kinerja karyawan dengan memakai konsep yang dikembangkan Goodhue \& Thompson (1995).

Dalam penelitian tersebut didapati Kesesuaian Tugas-Teknologi berpengaruh positif serta signifikan terhadap Pemanfaatan TI, berarti penelitian ini sesuai dengan penelitian Joko Susilo (2016). Hubungan yang signifikan ini menunjukkan bahwa semakin tinggi variabel Kesesuaian Tugas-Teknologi akan mengarah pada Pemanfaatan yang juga lebih besar.

Penelitian ini juga sesuai penelitian Godhue \& Thompson (1995) yang meneliti tentang "Task-Technology Fit \& Individal Performance" dan dari penelitian tersebut didapati bahwa evaluasi pengguna terhadap Kesesuaian TugasTeknologi akan mempengaruhi Pemanfaatan sistem informasi oleh individu.

Kesesuaian tugas teknologi siakad dan UB Feeder dirasakan sangat bermanfaat oleh operator dimana tugas pekerjaanya membutuhkan dua sistem tersebut karena operator sudah merasakan kesesuaian dan merasa bermanfaat dalam penyelesaian tugas pekerjaannya. Nampak nilai loading faktor TTF.5 (0.914) yaitu kemudahan penggunaan dengan rata-rata jawaban responden yaitu 4.08, nilai ini lebih besar dari TTF.1 (kualitas; loading factor 0.830), TTF.2 (penempatan; loading factor 0.742), TTF.4 (kesesuaian; loading factor 0.800), TTF.6 (ketepatan waktu produksi; loading factor 0.847), TTF.7 (keandalan sistem; loading factor 0.779) dan TTF.8 (hubungan dengan pengguna lain; loading factor 0.860 ), ini menandakan saat operator merasa kemudahan penggunaan Siakad dan UB Feeder maka operator akan tetap menggunakan sistem tersebut sebab memiliki kualitas yang dinterpretasikan sangat tinggi (4.29) oleh operator.

Pemanfaatan Siakad dan UB Feeder oleh operator cukup tinggi hal ini dapat dilihat pada nilai loading faktor Ut.3 (0.867) yaitu norma sosial dengan rerata jawaban responden 4.02, dimana nilai ini lebih besar dari loading faktor UT.1 (kepercayaan; 0.764), Ut.2 (mempengaruhi penggunaan; 0.765) dan Ut.4 (kebiasaan; 0.811). Ini mengindikasikan saat operator merasakan pemanfaatan Siakad dan UB Feeder telah sesuai dengan norma sosial atau aturan norma yang ada maka operator akan tetap menggunakan karena sudah memiliki kepercayaan menggunakanan sistem ini yang diinterpretasikan tinggi (4.11) oleh operator.

$$
\text { Pada Universitas Brawijaya jika }
$$

Kesesuaian Tugas-Teknologi tinggi maka meningkatkan Pemanfaatan Siakad dan UB Feeder oleh operator.

\subsubsection{Pengujian $\mathrm{H} 4$}

Pengujian $\mathrm{H} 4$ bertujuan untuk mengetahui apakah terdapat pengaruh positif antara Kesesuaian Tugas-Teknologi terhadap Dampak Kinerja Individu. Dari hasil pengolahan data diperoleh nilai koefisien path antara Kesesuaian Tugas-Teknologi terhadap Dampak Kinerja Individu sebesar 0.794 dan nilai $\mathrm{t}$ statistik sebesar 10.940 yang dinyatakan signifikan karena nilai t-statistik penelitian lebih besar dari $\mathrm{t}$ tabel.

Jadi dapat disimpulkan bahwa Kesesuaian Tugas-Teknologi berpengaruh terhadap Dampak Kinerja Individu secara positif dan signifikan didukung secara statistik oleh data penelitian yang ada.

Penelitian Khoirul Habib Syahroni (2014) bertujuan menganalisis pengaruh faktor pemanfaatan teknologi informasi, kesesuaian tugas-teknologi informasi, dan kepercayaan atas teknologi informasi terhadap kinerja individual. Hasil dari penelitian menunjukkan faktor pemanfaatan teknologi informasi, faktor kesesuaian tugas-teknologi, dan faktor kepercayaan atas teknologi informasi berpengaruh signifikan terhadap kinerja individual. Hubungan signifikan antara 
Kesesuaian Tugas-Teknologi terhadap dampak kinerja menunjukkan bahwa semakin besar Kesesuaian Tugas-Teknologi maka akan mengarah pada dampak kinerja individu yang lebih besar juga.

Hal ini tidak sejalan dengan Kuo-Yu Hang \& Yea-Ru Chuang (2016) yang meneliti “ $A$ Task-technology Fit View of Job Search Website impact on Performance Effect: An Empirical Analysis from Taiwan" dengan bertujuan menyelidiki faktor-faktor yang mempengaruhi penggunaan ponsel cerdas mahasiswa untuk tujuan akademik dengan mengidentifikasi kesesuaian tugas-teknologi (TTF) dari telepon pintar. Dari hasil penelitian tersebut didapatkan hasil penelitan bahwa :

- Task-technology fit secara positif mempengaruhi hasil yang diharapkan dari penggunaan situs pencarian kerja (JSW);

- Kesesuaian Tugas-teknologi sesuai secara positif mempengaruhi sikap terhadap penggunaan JSW;

- Hasil yang diharapkan dari penggunaan JSW akan secara positif mempengaruhi pemanfaatan JSW;

- Sikap terhadap penggunaan JSW memengaruhi pemanfaatan JSW;

- Norma sosial secara positif berpengaruh terhadap pemanfaatan JSW;

- Kebiasaan secara positif mempengaruhi pemanfaatan JSW;

- Kondisi yang memfasilitasi secara positif mempengaruhi pemanfaatan JSW;

- Kesesuaian tugas-teknologi secara negatif memengaruhi durasi pengangguran pencari kerja;

- JSW utilization negatively influences jobseeker unemployment durations;

- Pemanfaatan JSW secara negatif mempengaruhi durasi pengangguran pencari kerja.

Dari hasil penelitian didapati bahwa Kesesuaian tugas-teknologi (Task Technology Fit/ TTF) secara negatif mempengaruhi kinerja (durasi) pengangguran pencari kerja artinya semakin tinggi Kesesuaian tugas-teknologi (Task Technology Fit/ TTF) maka makin kecil kinerja (durasi) pengangguran pencari kerja.

Pada penelitian dengan judul "The influence of smartphones on academic performance: The development of the technology to performance chain model" yang dilakukan oleh Yong Jeong Yi, Soeun You \& Beom Jun Bae (2019) yang bertujuan menyelidiki faktor yang mempengaruhi penggunaan smartphone mahasiswa untuk tujuan akademik dengan mengidentifikasi kesesuaian tugas-teknologi (TTF) dari smartphone diperoleh hasil;

- TTF dalam smartphone memiliki efek positif pada attitude (sikap) terhadap penggunaan smartphone, jadi Persepsi TTF yang lebih tinggi dapat meningkatkan pemanfaatan ponsel cerdas siswa untuk tujuan akademik;

- attitude (sikap) terhadap penggunaan smartphone memiliki efek positif \& signifikan pada penggunaan smartphone (Ut);

- Sikap terhadap penggunaan smartphone memiliki efek positif \& signifikan pada penggunaan smartphone (Ut);

- Norma sosial memiliki efek positif pada \& signifikan penggunaan smartphone (Ut);

- Kondisi fasilitasi mempunyai efek positif \& signifikan pada penggunaan smartphone (Ut);

- TTF memiliki efek positif \& signifikan pada dampak yang dirasakan dari smartphone pada kinerja akademik individu (PI);

- Menggunakan smartphone (Ut) memiliki efek positif \& signifikan pada kinerja akademik individu (PI).

Dari hasil penelitian didapati bahwa Kesesuaian tugas-teknologi berpengaruh positif dan signifikan terhadap Dampak Kinerja Individu.

Penelitian ini sejalan dengan penelitian Godhue \& Thompson (1995) yang meneliti tentang "Task-Technology Fit and Individal Performance" yang bertujuan mengusulkan model teoritis komprehensif yang menggabungkan wawasan berharga dari dua aliran penelitian yaitu TAM dan TTF, hasilnya yaitu ;

- evaluasi pengguna terhadap kesesuaian tugas-teknologi dipengaruhi secara signifikan karakteristik tugas dan karakteristik teknologi;

- evaluasi pengguna terhadap Kesesuaian Tugas-Teknologi mempengaruhi secara signfikan Pemanfaatan sistem informasi oleh individu;

- evaluasi pengguna terhadap kesesuaian teknologi tugas memiliki kekuatan penjelas tambahan dalam memprediksi secara signifikan dampak kinerja yang dirasakan di luar dari pemanfaatan itu sendiri. 
Diperoleh hasil bahwa kesesuaian teknologi tugas berpengaruh signifikan terhadap dampak kinerja tanpa pengaruh Pemanfaatan.

Kesesuaian tugas teknologi Siakad dan UB Feeder dirasakan memiliki dampak terhadap kinerja operator dimana tugas pekerjaanya membutuhkan dua sistem tersebut karena operator merasakan kesesuaian dan merasakan implikasi dari penggunaannya yang bermanfaat terhadap dampak kinerjanya. Hal ini nampak pada nilai loading faktor TTF.5 (0.914) yaitu kemudahan penggunaan dengan rata-rata jawaban responden yaitu 4.08, nilai ini lebih besar dari TTF.1 (kualitas; loading factor 0.830), TTF.2 (penempatan; loading factor 0.742), TTF.4 (kesesuaian; loading factor 0.800), TTF.6 (ketepatan waktu produksi; loading factor 0.847), TTF.7 (keandalan sistem; loading factor 0.779) dan TTF.8 (hubungan dengan pengguna lain; loading factor 0.860) K0ndisi ini mengindikasikan saat operator merasa mudah menggunakan Siakad dan UB Feeder karena memiliki dampak positif terhadap kinerja operator maka operator akan tetap menggunakan sistem tersebut sebab memiliki kualitas yang dinterpretasikan sangat tinggi (4.29) oleh operator.

Dampak kinerja operator dengan adanya kesesuaian tugas dan teknologi dirasakan sangat menunjang operator dalam menyelesaikan pekerjaannya. Hal ini nampak pada nilai loading factor PI.1 (0.899) yaitu efektifitas dengan rerata jawaban responden 4.12, nilai ini lebih besar dari PI.2 (Produktifitas; loading factor 0.891) dan PI.3 (Kinerja; loading factor 0.885). Kondisi ini menandakan saat operator merasakan efektifitas penggunaan siakad maupun Ub Feeder sebagai akibat dari kesesuaian tugas dengan teknologinya maka operator akan senang memakai sistem tersebut karena mempunyai produktivitas yang diinterpretasikan oleh operator sangat tinggi (4.21).

Pada penelitian yang dilakukan di Universitas Brawijaya didapatkan bahwa Kesesuaian Tugas-Teknologi berpengaruh positif dan signifikan terhadap Dampak Kinerja Individu. Semakin besar Kesesuaian TugasTeknologi akan meningkatkan Dampak Kinerja Individu.

\subsubsection{Pengujian H5}

Pengujian $\mathrm{H} 5$ bertujuan mengetahui apakah terdapat pengaruh positif Pemanfaatan terhadap Dampak Kinerja Individu. Dari hasil pengolahan data diperoleh koefisien path antara
Pemanfaatan terhadap Dampak Kinerja Individu 0.321 dan $\mathrm{t}$ statistik, yang dinyatakan signifikan karena nilai t-statistik penelitian lebih besar dari $\mathrm{t}$ tabel. Jadi dapat disimpulkan bahwa mempengaruhi Dampak Kinerja Individu secara positif dan signifikan didukung secara statistik oleh data penelitian yang ada.

Nurul Huda Agustiani (2010) melakukan penelitian "Pengaruh Pemanfaatan Sistem Informasi Akademik Terpadu (SIKADU) terhadap Kinerja Individual dengan Kemudahan Penggunaan sebagai Variabe1 Moderating" yang bertujuan untuk mengetahui pengaruh pemanfaatan SIKADU terhadap kinerja individual, dan mengetahui pengaruh pemanfaatan SIKADU terhadap kinerja individual yang dimoderasi oleh kemudahan penggunaan didapatkan hasil bahwa ;

- Pemanfaatan Sikadu terhadap kinerja individu berpengaruh positif dan signifikan

- Pemanfaatan Sikadu terhadap kinerja individual dengan dimoderasi Kemudahan Penggunaan Sikadu berpengaruh negatif dan signifikan

Didapatkan hasil bahwa Pemanfaatan Sikadu terhadap kinerja individu berpengaruh positif dan signifikan.

Dwi Himma Aulia (2013) meneliti "Pengaruh Pemanfaatan Sistem Infornnasi Akademik (SISKA) terhadap Kinerja Individual dengan Kegunaan Persepsian sebagai variabe1 Moderating" bertujuan untuk mengetahui pengaruh pemanfaatan SISKA terhadap kinerja individual dan untuk mengetahui pengaruh pemanfaatan SISKA terhadap kinerja individual yang dimoderasi oleh kegunaan persepsian diperoleh;

- Variabel Pemanfaatan Academik Information System (AIS) berpengaruh positif dan signifikan terhadap kinerja individual .

- Variabel moderating kemudahan penggunaan tidak berpengaruh secara signifikan terhadap pemanfaatan AIS dan kinerja Individual. Variabel kemudahan penggunaan bukan merupakan variabel moderating.

Diperoleh hasil bahwa Pemanfaatan (Ut) AIS berpengaruh positif serta signifikan terhadap kinerja individual (PI).

Sejalan dengan penelitian Joko Susilo (2016) yaitu "Analisis Faktor-Faktor Yang Mempengaruhi Pemanfaatan TI dan Pengaruh nya Terhadap Kinerja Karyawan PT. Inalum (Persero)" didapatkan hasil bahwa pemanfaatan (Ut) teknologi informasi (Z) memiliki pengaruh 
positif dan signifikan secara statistik terhadap kinerja(PI) karyawan (Y).

Pada penelitian yang dilakukan oleh Ni luh Ayu Artha Dewi \& Ida Bagus Dharmadiaksa (2017) dengan judul "Pengaruh Efektifitas SIA, Pemanfaatan TI dan Kemampuan Teknis Pemakai SIA terhadap Kinerja Individu" bertujuan untuk mengetahui pengaruh efektivitas sistem informasi akuntansi terhadap kinerja individu pada Koperasi Simpan Pinjam di Kabupaten Karangasem; mengetahui pengaruh pemanfaatan teknologi informasi terhadap kinerja individu pada Koperasi Simpan Pinjam di Kabupaten Karangasem; dan mengetahui kemampuan teknis pemakai sistem informasi akuntansi terhadap kinerja individu pada Koperasi Simpan Pinjam di Kabupaten Karangasem didapatkan;

- Menerima hipotesis H1 yang menyatakan efektivitas sistem informasi akuntansi berpengaruh positif pada kinerja individu. Koperasi simpan pinjam yang mampu menghasilkan informasi yang dapat diterima secara tepat waktu, akurat dan dapat dipercaya dapat meningkatkan kinerja individu di koperasi simpan pinjam. Semakin baik sistem informasi akuntansi yang diterapkan dalam suatu organisasi, maka semakin meningkat kinerja individu dalam organisasi tersebut.

- Pemanfaatan teknologi informasi berpengaruh positif dan signifikan terhadap kinerja individu. Koperasi simpan pinjam yang mampu menghasilkan informasi yang dapat diterima secara tepat waktu, akurat dan dapat dipercaya yang nantinya dapat meningkatkan kinerja individu koperasi simpan pinjam.

- Kemampuan teknis pemakai sistem informasi akuntansi berpengaruh signifikan terhadap kinerja individu. Semakin tinggi tingkat kemampuan teknis pemakai sistem informasi akuntansi, maka semakin tinggi kinerja individu.

Diperoleh bahwa pemanfaatan (Ut) informasi berpengaruh positif dan signifikan terhadap kinerja (PI).

Demikian halnya penelitian yang dilakukan oleh Khoirul Habib Syahroni (2014) yang berjudul Pegaruh Pemanfaatan Teknologi Informasi, Kesesuaian Tugas-Teknologi Informasi dan Kepercayaan atas Teknologi Informasi terhadap Kinerja Individual yang bertujuan untuk menganalisis pengaruh faktor pemanfaatan teknologi informasi terhadap kinerja individual; untuk menganalisis pengaruh faktor kesesuaian tugas-teknologi informasi terhadap kinerja individual; dan untuk menganalisis pengaruh faktor kepercayaan atas teknologi informasi terhadap kinerja individual didapatkan hasil:

- Pemanfaatan teknologi informasi berpengaruh secara signfikan terhadap kinerja individual;

- Kesesuaian tugas-teknlogi informasi berpengaruh secara signifikan kinerja individual;

- Kepercayaan atas teknologi informasi juga berpengaruh secara signifikan terhadap kinerja individual.

Diperoleh bahwa pemanfaatan (Utilization/Ut) signifikan berpengaruh terhadap kinerja (Performance Impact/ PI) individual.

Tidak sejalan dengan penelitian Kuo-Yu Hang \& Yea-Ru Chuang (2016) yang meneliti "A Task-technology Fit View of Job Search Website impact on Performance Effect: An Empirical Analysis from Taiwan" yang bertujuan untuk menyelidiki faktor-faktor yang mempengaruhi penggunaan ponsel cerdas mahasiswa untuk tujuan akademik dengan mengidentifikasi kesesuaian tugas-teknologi dari telepon pintar. Dari hasil penelitian didapati bahwa Pemanfaatan (Utilization/ Ut) secara negatif mempengaruhi kinerja (Performance Impact/ PI) pengangguran pencari kerja artinya semakin tinggi Pemanfaatan (Utilization/ Ut) maka makin kecil kinerja (durasi) pengangguran pencari kerja.

Pada penelitian yang dilakukan oleh Yong Jeong Yi, Soeun You \& Beom Jun Bae (2019) dengan judul "The influence of smartphones on academic performance: The development of the technology to performance chain model" bertujuan untuk menyelidiki faktor-faktor yang mempengaruhi penggunaan smartphone mahasiswa untuk tujuan akademik dengan mengidentifikasi kesesuaian tugas-teknologi (TTF) dari smartphone. Dari hasil penelitian didapati bahwa penggunaan-pemanfaatan (utilization/ Ut) berpengaruh positif dan signifikan terhadap Dampak Kinerja Individu (Performance ImpactI PI).

Demikian juga penelitian Godhue \& Thompson (1995) yang berjudul "TaskTechnology Fit and Individual Performance" dengan tujuan untuk mengusulkan model teoritis komprehensif yang menggabungkan wawasan berharga dari aliran TAM dan TTF. 
- evaluasi pengguna terhadap kesesuaian tugas-teknologi di pengaruhi secara signifikan oleh variabel karakteristik tugas dan karakteristik teknologi;

- evaluasi pengguna terhadap Kesesuaian Tugas-Teknologi berpengaruh secara signifikan Pemanfaatan sistem informasi oleh individu;

- evaluasi pengguna terhadap kesesuaian teknologi-tugas akan memiliki kekuatan penjelas tambahan dalam memprediksi secara signifikan dampak kinerja yang dirasakan di luar dari pemanfaatan itu sendiri. Diperoleh hasil bahwa Pemanfaatan (Utilization/ Ut) akan berpengaruh signifikan terhadap dampak kinerja (Performance lmpact/PI) namun akan lebih besar dampaknya jika kesuaian tugasteknologi (Task-Technology Fit/TTF) bersamasama dengan Pemanfaatan (Utilization/Ut) mempengaruhi dampak kinerja (Performance ImpactI PI).

Pada penelitian ini pemanfaatan Siakad dan UB Feeder oleh operator cukup tinggi hal ini dapat dilihat pada nilai loading faktor Ut.3 (0.867) yaitu norma sosial dengan rerata jawaban responden 4.02, nilai ini lebih besar dari loading faktor UT.1 (kepercayaan; 0.764), Ut.2 (mempengaruhi penggunaan; 0.765) dan Ut.4 (kebiasaan; 0.811). Ini mengindikasikan saat operator merasakan pemanfaatan Siakad dan UB Feeder telah sesuai dengan norma sosial atau aturan norma yang ada maka operator akan tetap menggunakan karena operator merasa memiliki kepercayaan dengan menggunakan sistem ini yang diinterpretasikan tinggi (4.11) oleh operator.

Dampak kinerja yang dirasakan operator dengan adanya pemanfaatan Siakad dan UB Feeder adalah sangat menunjang produktivitas operator dalam menyelesaikan pekerjaannya. Hal ini nampak pada nilai loading factor PI.1 (0.899) yaitu efektifitas dengan rerata jawaban responden 4.12, nilai ini lebih besar dari PI.2 (Produktifitas; loading factor 0.891) dan PI.3 (Kinerja; loading factor 0.885). Kondisi ini menandakan saat operator merasakan efektifitas penggunaan siakad maupun Ub Feeder sebagai akibat dari pemanfaatan teknologi maka operator merasa nyaman menggunakan sistem karena mempunyai produktivitas yang diinterpretasikan oleh operator sangat tinggi (4.21).

Pada penelitian yang dilakukan di Universitas Brawijaya diperoleh hasil bahwa Pemanfaatan (Utilization/ Ut) akan berpengaruh positif dan signifikan terhadap dampak kinerja (Performance lmpact/PI). Makin tinggi pemanfaatan Siakad dan UB-Feeder maka makin besar dampaknya ter hadap dampak kinerja (Performance Impact/PI).

\section{KESIMPULAN DAN SARAN Kesimpulan}

1. Karakteristik Tugas (Task Characteristic/TaskC) berpengaruh positif dan signifikan terhadap Kesesuaian TugasTeknologi (Task-Technology Fit/TTF), Hipotesis 1 diterima;

2. Karakteristik Teknologi (Technology Characteristic/TechC) berpengaruh positif dan signifikan terhadap Kesesuaian TugasTeknologi (Task-Technology Fit/TTF), Hipotesis 2 diterima ;

3. Kesesuaian Tugas-Teknologi (TaskTechnology Fit/TTF) berpengaruh positif dan signifikan terhadap Pemanfaatan (Utilization/Ut), Hipotesis 3 diterima;

4. Kesesuaian Tugas-Teknologi (TaskTechnology Fit/TTF) berpengaruh positif dan signifikan terhadap Dampak Kinerja Individu (Performance Impact/PI), Hipotesis 4 diterima;

5. Kesesuaian Tugas-Teknologi (TaskTechnology Fit/TTF) berpengaruh positif dan signifikan terhadap Dampak Kinerja Individu (Performance Impact/PI), Hipotesis 5 diterima.

\section{Saran}

Berdasarkan hasil penelitian, saran yang dapat diberikan daIam penelitian;

1. Bagi Organisasi

a. Universitas Brawijaya dapat memakai hasil penelitian ini sebagai acuan daIam mempertahankan dimensi yang sudah baik dan meningkatkan dimensi yang kurang agar pemanfaatan Siakad dan UB Feeder benar-benar sesuai dengan kesesuaian tugas dari pengguna sistem sehingga dampak kinerjanya menjadi efektif dan efisien;

b. Universitas Brawijaya dapat menggunakan hasil penelitian ini sebagai acuan manajemen daIam menentukan kebijakan yang berhubungan dengan pemanfaatan Siakad dan UB Feeder;

c. Siakad hendaknya secara otomatis dapat berinteraksi dengan UB Feeder 
sehingga operator tidak perlu melakukan pengolahan data ulang;

d. Hendaknya terdapat perbaikan pada Siakad agar penggunaannya dapat secara maksimal.

2. Bagi Penelitian yang akan dating:

a. Penelitian selanjutnya dapat meneliti semua pengguna (penambahan jumlah sampel) sistem Siakad dan UB Feeder;

b. Penelitian ini bisa dilakukan di perguruan tinggi lain sehingga hasilnya dapat digeneralisasikan.

\section{DAFTAR PUSTAKA}

Amin, Fadillah. 2017. Bahan Ajar Teori Admnistrasi/ Manajemen Pendidikan. Fakultas Ilmu Administrasi Universitas Brawijaya.

Indrayani, Etin. 2013. Management of Academic Information System (AIS) at Higher Education in The City Of Bandung. Lecturer in Institute of Home Affairs Government (IPDN). Sumedang-Jawa Barat Indonesia. 13th International Educational Technology Conference. Procedia - Social and Behavioral Sciences 103 ( 2013 ) $628-636$. www.sciencedirect.com.

Indrajit, Richardus Eko. 2010. Pengantar Konsep Dasar, Manajemen Sistem Informasi dan Teknologi Informasi. STMIK Perbanas Renaissance Center.

Alkawaldeh, Nayef. 2010. Barriers to Utilizing ICT for Educational Purposes in Jordan. Swedish Business School, E-Government Program.

Rizal, Irhas Chaerur. Ramandani, Rizki. Romadhon, Fahmi. Randa, M.Arif. Rahmat. M. 2013. Analisis Sistem Informasi Akademik Online di Universitas Diponegoro Semarang. Program Studi Teknik Informatika. Fakltas Ilmu Komputer. Universtas Bina Darma. Palembang. Diakses 02 Nopember 2017 pukul 22.37 WIB.

Al Fatta, Hanif. 2007. Analisis dan Perancangan Sistem Informasi untuk Keunggulan Bersaing Perusahaan dan Organisasi Modern. CV Andi Offset.
Hutahean, Jeperson. 2014. Konsep Sistem Informasi. Edisi I. Cetakan I. Yogyakarta Deepublish. Agustus 2014.

Saepuloh, Asep. 2018. Analisis Technology to Performance Chain (TPC) dalam Implementasi SIMDA Keuangan Versi 2.7 Bebasis Akrual (Ppt). Fakultas Ekonomi dan Bisnis, Universitas Bengkulu.

Jogiyanto. 2008. Sistem Informasi Keperilakuan, Edisi Revisi. Yogyakarta. Andi.

Agustiarni, Nurul Huda. 2010. Pengaruh Pemanfaatan Sistem Informasi Akademik Terpadu (Sikadu) Terhadap Kinerja Individual dengan Kemudahan Penggunaan Sebagai Variabel Moderating. Fakultas Teknik Universitas Negeri Semarang.

Hendrawati, Tuty. 2013. Analisis Penerimaan Sistem Informasi Integrated Library System (INLIS) : Studi Kasus di Perpustakaan Nasional RI. Visi Pustaka Volume 15, Nomor 3, Desember 2013.

Goodhue, Dale L.; Thompson, Ronald L. TaskTechnology Fit and Individual Performance. MIS quarterly, Jun 1995, 19, 2, ABI/INFORM Global pg.213.

Susanti, Vivi Ani. 2006. Teknologi Tugas yang Fit dan Kinerja Individual. Jurnal Akuntansi dan Keuangan Vol.8 No.1Mei 2006:24-34 https://media.neliti.com/media/publicatio ns/75199-ID-none.pdf. 